شناسايى منشا ذرات معلق در اتمسفر با استفاده از ويزّگىهاى زئوشيميايى عناصر ردياب (مطالعه موردى: شهر كرمانشاه)

\author{
زينب نظرى "، نعمت الله خراسانى '، سادات فيضنيا' و محمود كرمى'

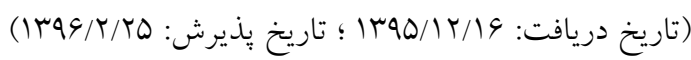

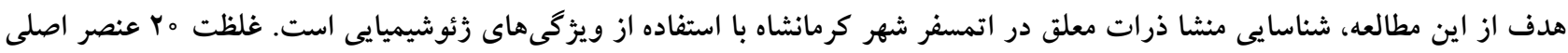

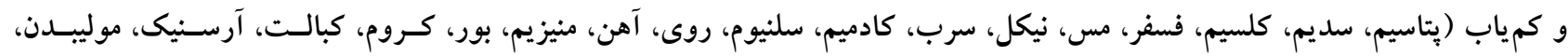

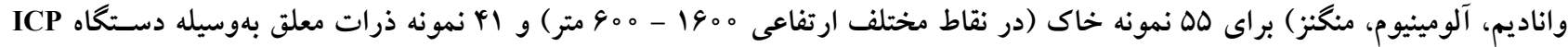

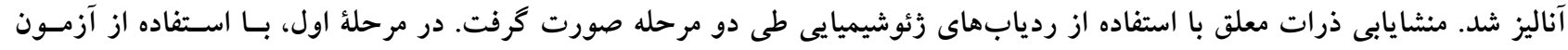

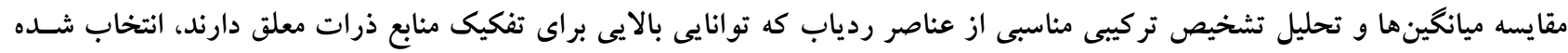

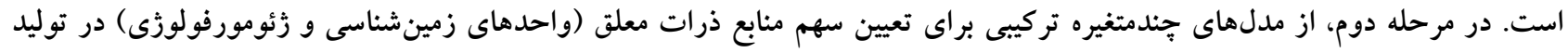

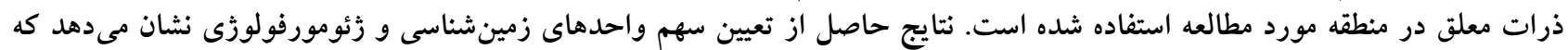

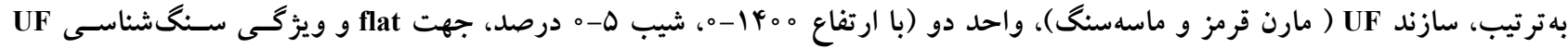

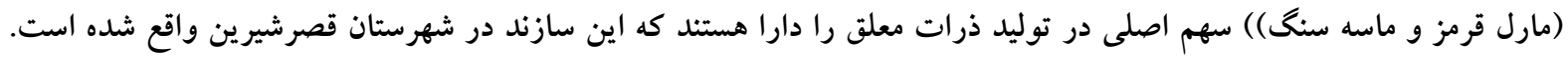

وازههاى كليدى: ذرات معلق، سهم، مدلهاى جندمتغيره تركيبى، منشا طبيعى

1. كروه محيط زيست، برديس كشاوززى و منابع طبيعى، دانشخاه تهر ان

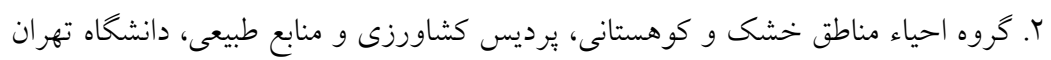

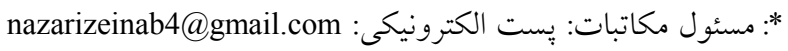


زيرحوضهها، واحدهاى سنگشناسى و يا خـاكشناسى در بـار

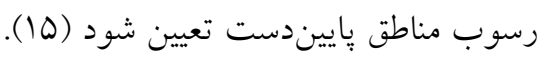

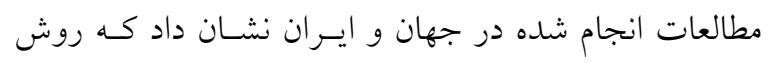

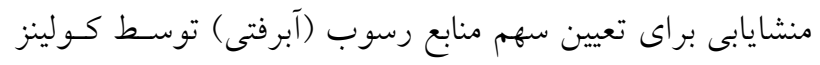

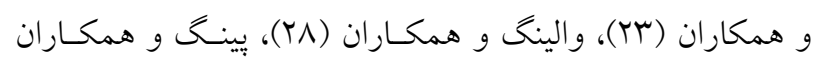

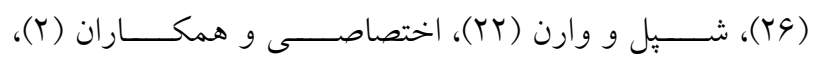

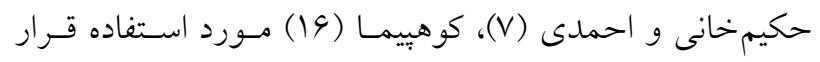

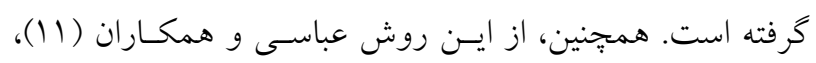

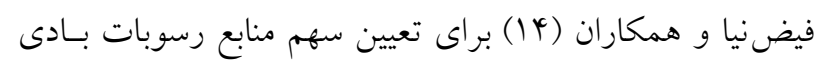
استفاده شده است. محققان ايرانى در زمينه ذرات معلق مطالعاتى انجام دادهانـــ

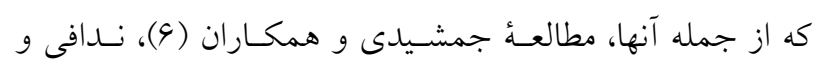

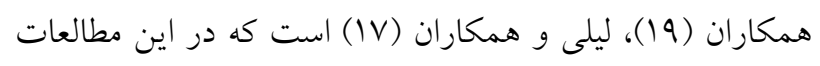
به بررسى روند تغييرات غلظت ذرات معلق در فصول مختلـف ورات يرداخته شده است. نتايج حاصل از تحقيق عطايى و احمدى (Y) (I) نشان داد كـه در فصل سرد سال شكل گيرى هسته كم ارتفاع و امواج غربى بـر

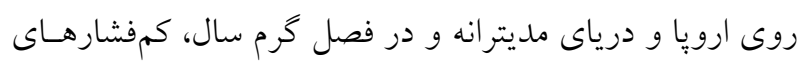
حرارتى عوامل ايجادكنندة كرد وغبار در منطقه هستند.

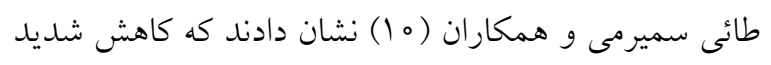

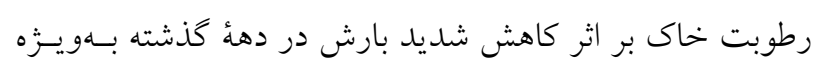

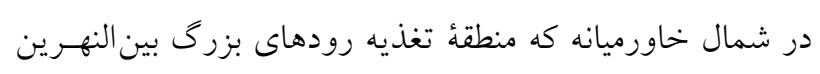

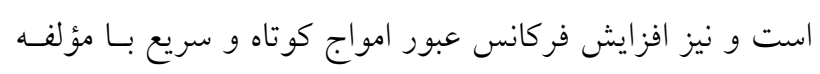

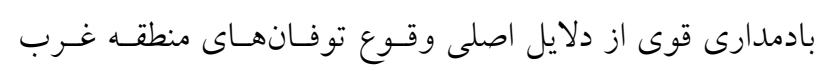

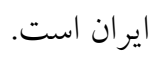

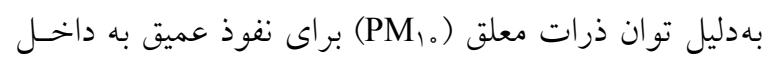

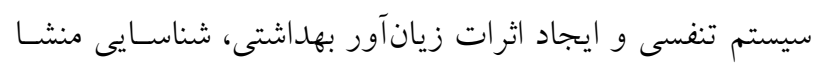

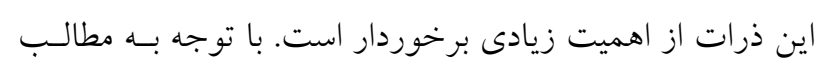

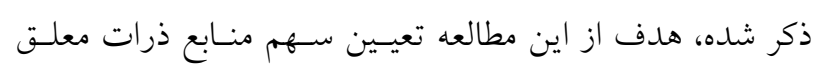

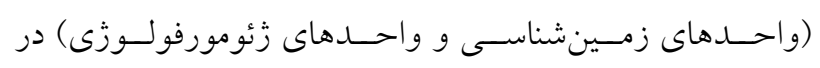

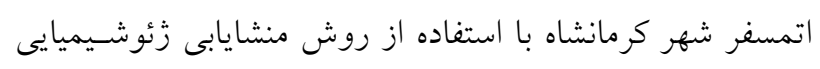

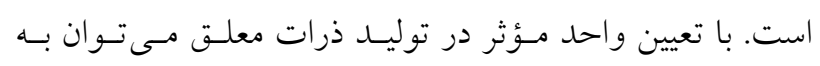

يكى از يديدههاى جوى مناطق خشك و نيمه خشك و يـا منـاطق

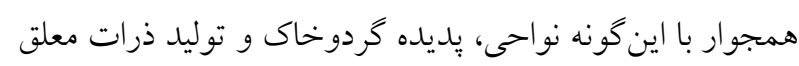
و رسوب است كه مخاطرات زيستمحيطى زيادى بـهمبـــاه دارد

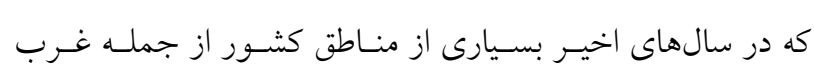

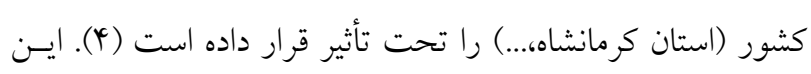
ذرات بسته به تركيب مى توانند بهصورت زيانآور سلامتى انسـان

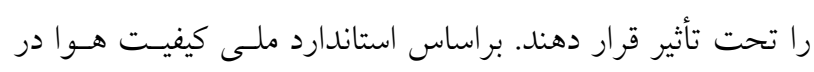

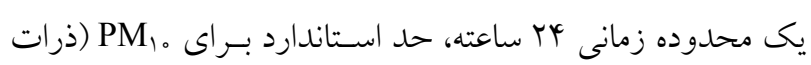

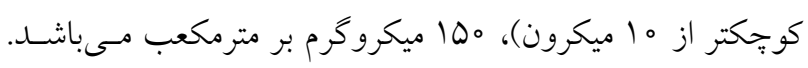

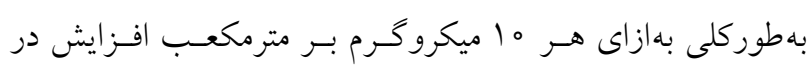

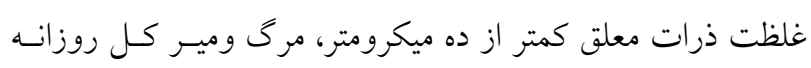
تقريباً تا يك درصد افزايش مى يابد (TI)

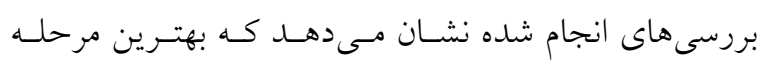

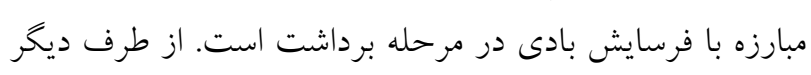

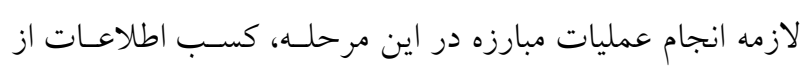

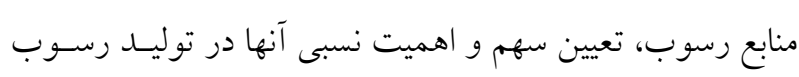

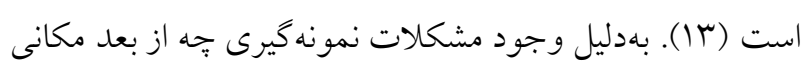

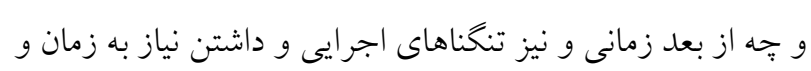

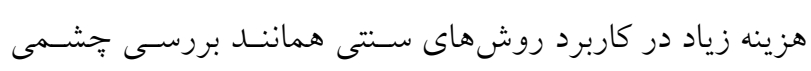
منابع رسوب از طريق عكسها و مشاهدات صحرايى، استفاده از

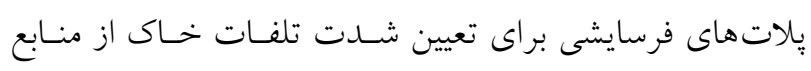

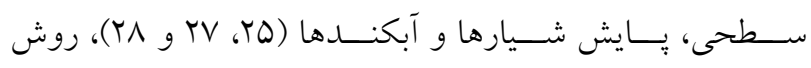

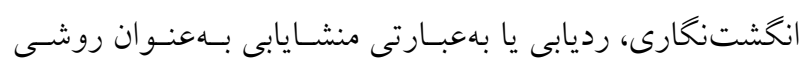

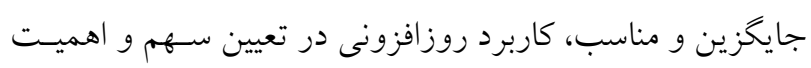

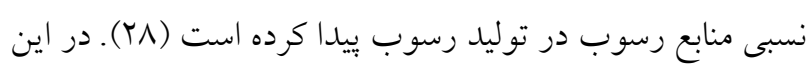

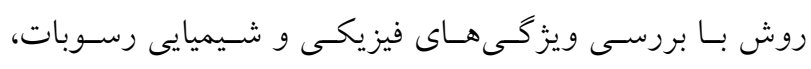

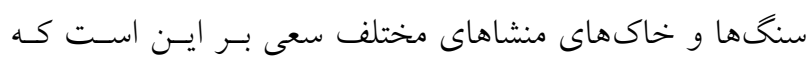

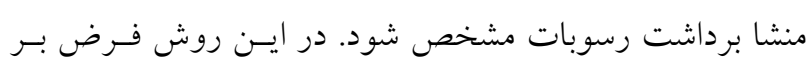

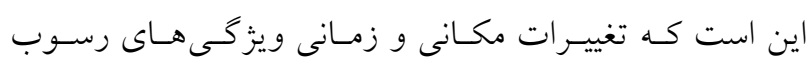

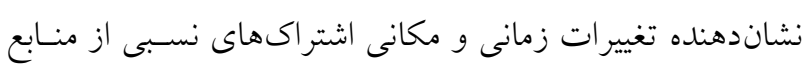

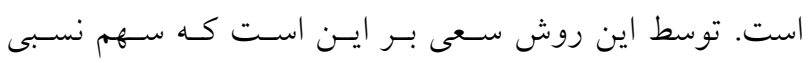


جدول ا. مساحت انواع كاربرىها در منطقه مورد مطالعه

\begin{tabular}{|c|c|c|c|c|c|c|}
\hline $\begin{array}{c}\text { مرتع } \\
\text { (درصد) }\end{array}$ & (هرتع & جنگل & جنَال & اراضى زراعى & اراضى زراعى & شاربرى \\
\hline $\mathrm{V} / \mathrm{A}$ & $r \circ \Lambda \wedge \vee Q$ & $r / 9$ & $9 \vee 994$ & $11 / 9$ & roqrrl & كرمانشاه \\
\hline $1 / r$ & ryovr & $r / 9$ & VASIT & $r / 0$ & qurta & اسلام آباد غرب \\
\hline O/AT & 49194 & $\circ / \circ 0$ & $14 \pi 49$ & $1 / 4$ & rqIYK & سريل ذهاب \\
\hline $1 / V$ & $990 Y 9$ & $T / \Lambda$ & VYart & $1 / V$ & $40 \wedge 91$ & كيلان غرب \\
\hline V & luveqr & $0 / 10$ & GTM & $\circ / \Delta V$ & IOHGV & قصرشيرين \\
\hline MNGY & $0 V 9949$ & $9 / 0$ & YGNAGY & $11 / 9$ & $D \circ Y \circ Y T$ & مجموع \\
\hline
\end{tabular}

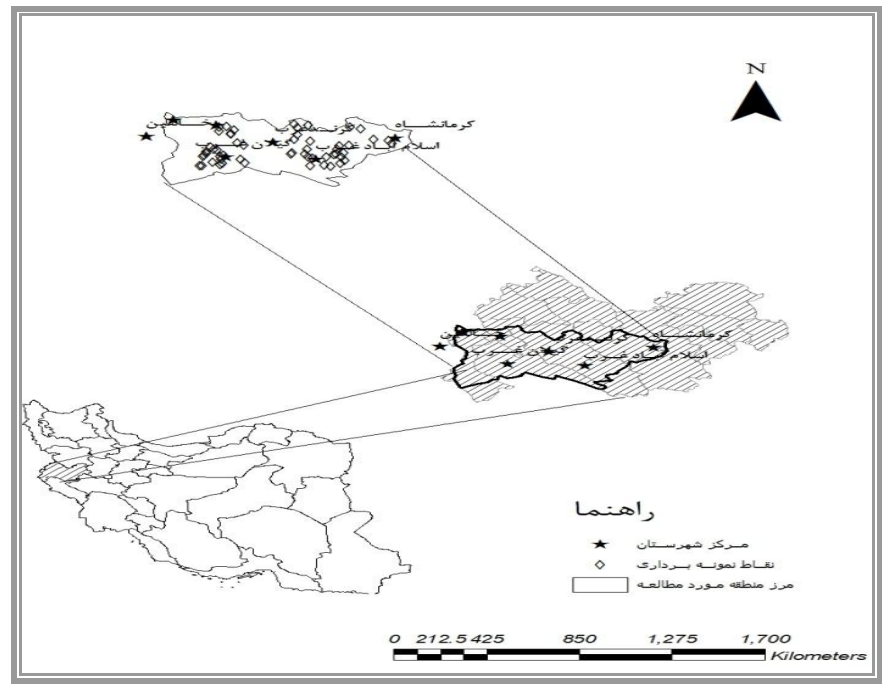

شكل 1. موقعيت منطقه مورد مطالعه

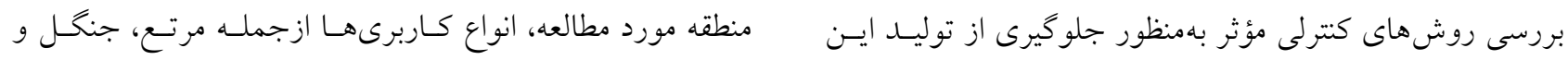

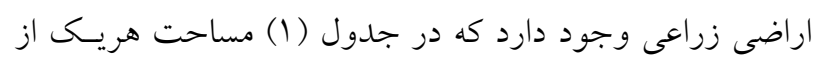
ذرات يرداخت.

آنها در شهرستانهاى در منطقه مورد مطالعه بيان شده است.

\section{مواد و روشها - (- ماد}

$$
\text { مطالعات هواشناسى و اقليم }
$$

معرفى منطقه مورد مطالعه

طبقهبندى آبووهواى استان كرمانشاه براسـاس روش دو مـارتن

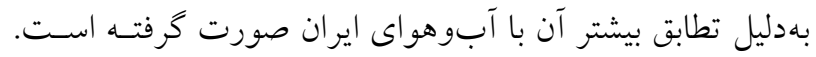

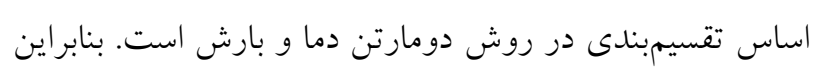

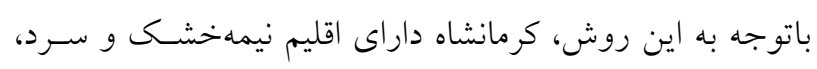

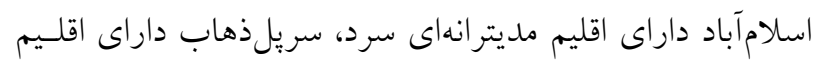

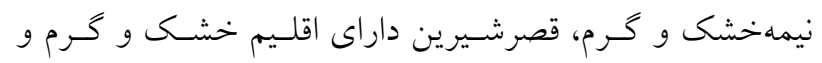

منطقه مورد مطالعه در محدوده غرب و جنسوبـغربى تـا مركسز استان كرمانشاه با مساحت

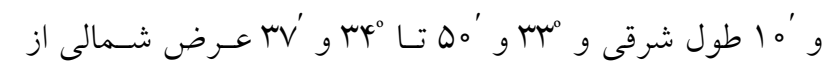

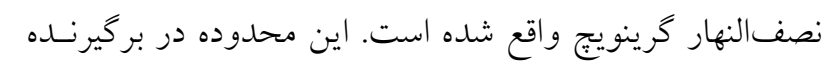

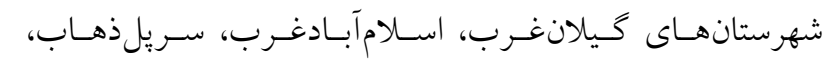

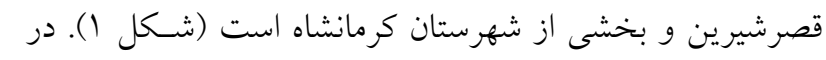


اداره كل حفاظت محسيط زيسـت اسـتان كرمانشـاه بـا موقعيـت

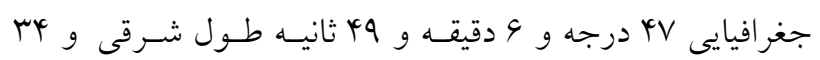

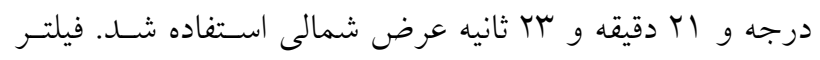

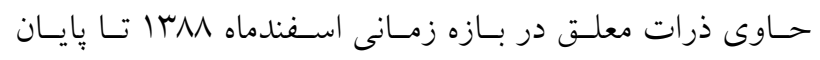
شهريور ارديبهشت برداشت شد. در مرحله بعد، فيلتر به قطعات مساوى تقسيم شد،

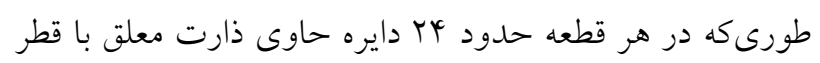

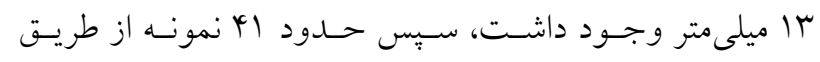
روش نمونهبردارى تصادفى سيستماتيكى انتخاب شد. سـبس درد درد

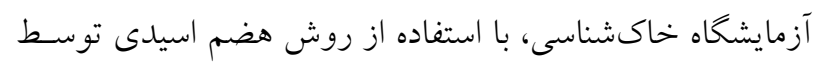

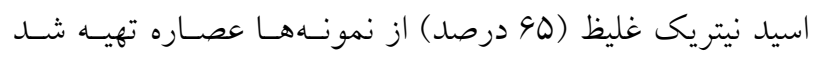

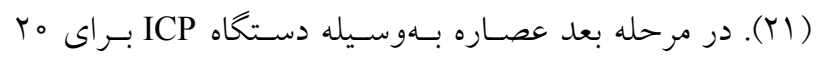

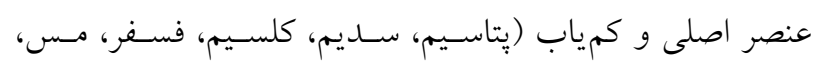

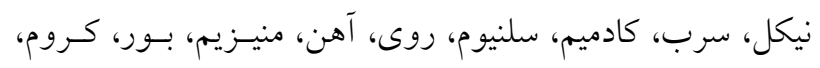

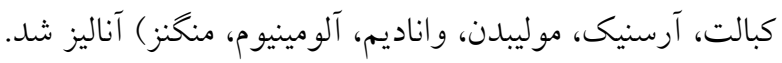

\section{روشهاى آمارى در منشايابى زئوشيميايى}

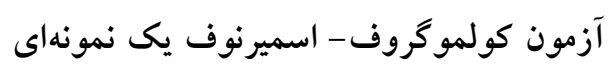

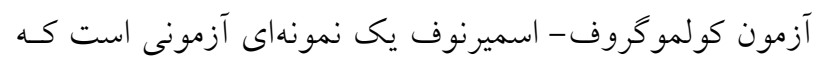

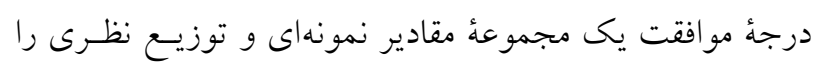

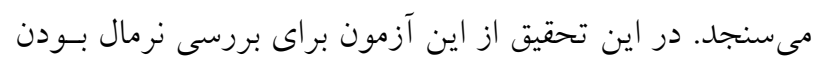

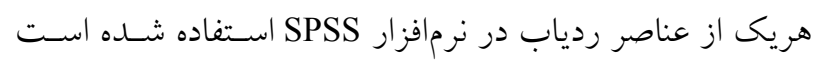

\section{آزمون مقايسه ميانخين ها}

در مواردى كه متغيرها در بيش از دو كروه اندازهكيرى شدهانـاند،

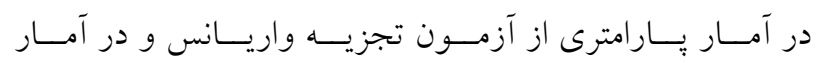

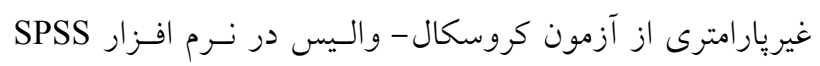

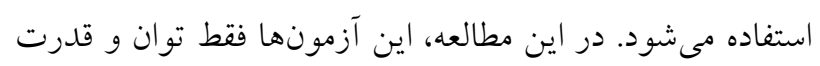

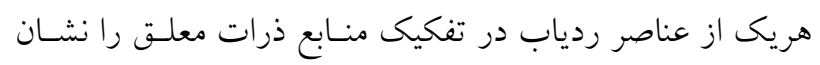

مى دهند (9).
كَلانغرب داراى اقليم نيمهخشك و سرد است (r).

$$
\text { رسم گل توفان }
$$

در اين مطالعه، بهمنظور تحليل كل طوفان، كمترين حسـ سـرعت

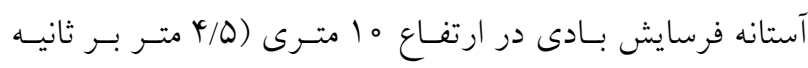
براساس خصوصيات زمينشناسى منطقه) بهعنوان سـرعت بايـهـ

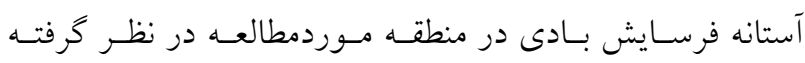

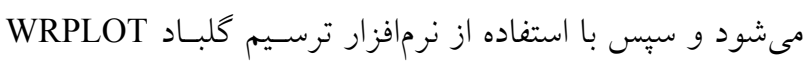

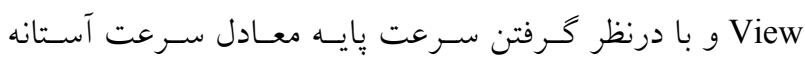
فرسايش بادى، كل توفان تهيه شد.

نمونه بردارى از واحدهاى زئومورفولوزى

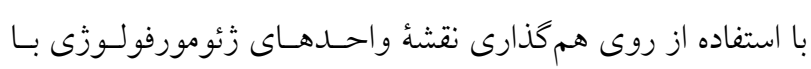

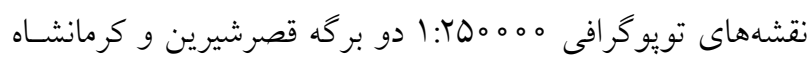
مشخص شد كه هريك از واحدها در خهه موقعيتى از منطقه واقـع

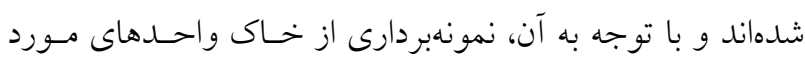

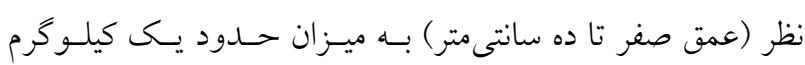

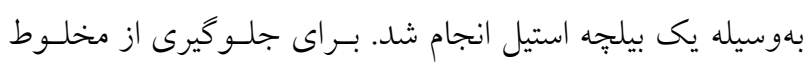

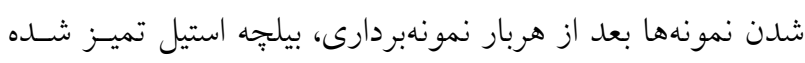

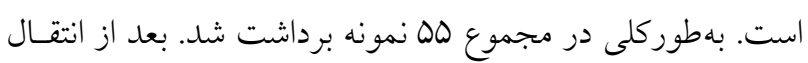

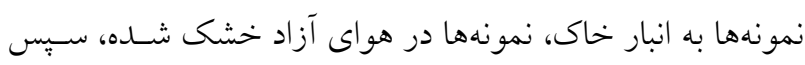

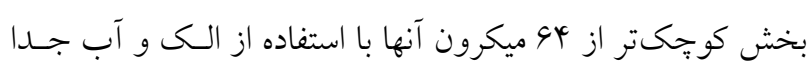

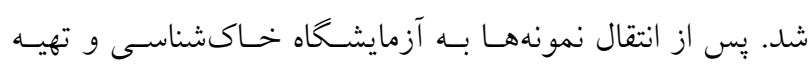
عصاره از آنها توسط محلول دىاتلين ترى آمين يتناسـتيكى اسـيد،

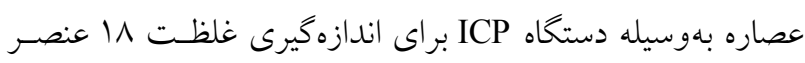

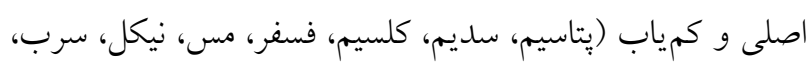

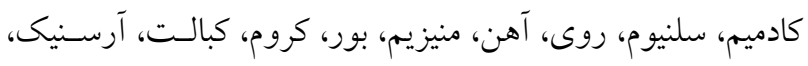

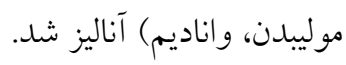

نمونهبردارى از ذرات معلق كمتر از ده ميكرومتر در اين تحقيق، بهمنظور نمونـهـــردارى از ذرات معلـق، دستيخاه

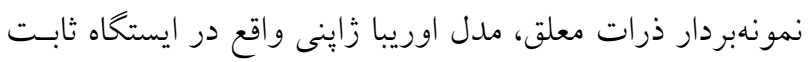


r- مجموع ضرايب سهم هريك از منابع رسـوب بايسـتى برابـر با يك باشد:

$\sum_{j=1}^{n} b_{j}=$

براى حـل ايسن معـادلات يكـى از روشهــا حـداقل كـردن

مجموع خطاهاى نسبى است. مجموع خطاهاى نسبى بهصورت زير محاسبه مىشود:

$E=\sum_{i=1}^{m}\left(\begin{array}{c}X_{i}-\hat{X}_{i} \\ X_{i}\end{array}\right)=\sum_{i=1}^{m}\left(\begin{array}{c}X_{i}-\left(\sum_{j=1}^{n} a_{i j} b_{j}\right. \\ X_{i}\end{array}\right)$

جوابهاى بهينه با استفاده از عمليات تكرار و سـعىوخطـا بدين نحو بهدست آمده است كه مقادير مختلف براى سهم منـابع رسوب (b ) انتخاب شـده و مقـدار تـابع هـدف (E) محاسبه مىشوند و اين عمليات تا جايى ادامه مىيابد كه E بـه كمتـرين مقدار خود برسد. در اين حالت مقادير انتخابى براى سهم منـابع رسوب، بهعنوان جوابهاى بهينه مورد قبول واقع مىشوند، اين كار براى تمام نمونههاى رسوب انجام شــده و از مقــادير سـهم

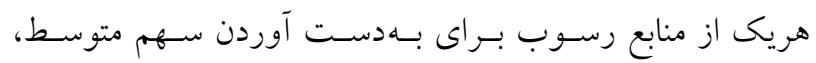
ميانخين گيرى مى شود (V و ر).

نتايج نتايج شناسايى و تفكيك بادهاى شديد و طوفــانزا از طريسق رسم كل طوفان

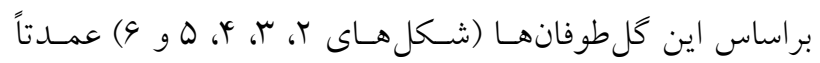

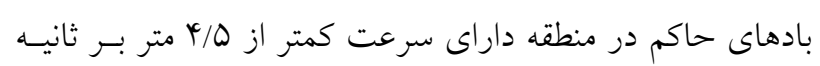

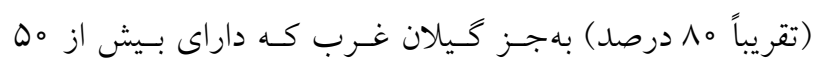

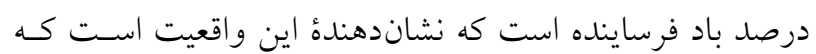

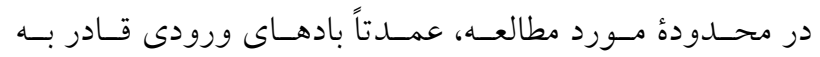
فرسايش خاك و ايجاد ذرات معلق (گردوغبار) نيستند.

بررسى آمارههاى توصيفى رديابهـا و شـاخص عامـل تـورم واريانس(VIF) و آزمون كولموكروف - اسميرنوف يك نمونهاى همان گونه كه در جدول (r) مشاهده مىشود، ضـريب تغييـرات
بررسى رابطهُ هم خطى جند

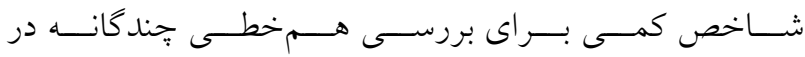

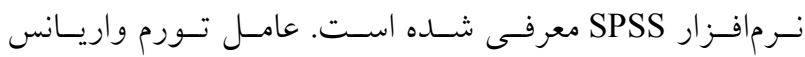
شاخصى است كه براى تعيـين (Variance Inflatation Factor) همخطى استفاده مىشود. بـين متغيرهـايى كـه مقـادير VIF آنهـا بيشتر از ه ا باشد، همخطى جند گُانه وجود دارد (9).

تحليل تشخيص در تحليـل تشـخيص در نـــرم افـزار SPSS بـــراى رسـيدن بـهـ

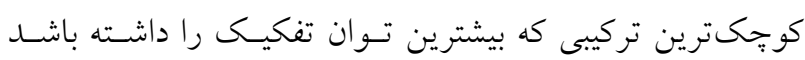
(تركيب بهينه)، از الخوريتم انتخاب قدمبهقدم استفاده مىشـود و از عمليات حداقل كردن آماره ويلكس لامدا بهره گرفته مىشود

تعيين سهم و اهميت نسبى منابع ذرات معلـق بـا اسـتفاده از

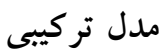

در مدلهاى جندمتغيره تركيبى از برنامهنويسى خطى براى حـل تعدادى از معادلات در نرمافزار EXCEL استفاده مىشـود و بــا حل اين معادلات سهم هريك از منابع مختلف بهدست مسى آيـد.

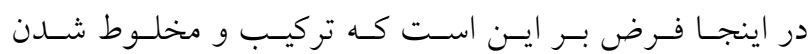

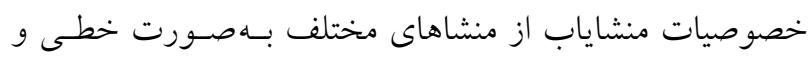
براساس معادله زير است: $\hat{X}_{i}=\sum_{j=1}^{n} a_{i j} b_{j}$

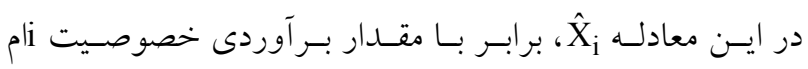
مقـدار ميـانخين خصوصسيات i أم در منبـع $a_{i j},(i=1, r, \ldots, n)$

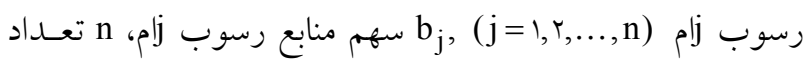
منابع رسوب و m تعداد خصوصيات منشاياب است. در حل اين معادلات دو شرط زير را بايد در نظر گرفت: 1- مقادير ضريب سهم هريك از منابع رسوب بايستى بين صفر

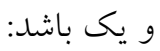
$\circ \mathrm{b} \leq 1$ 


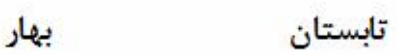

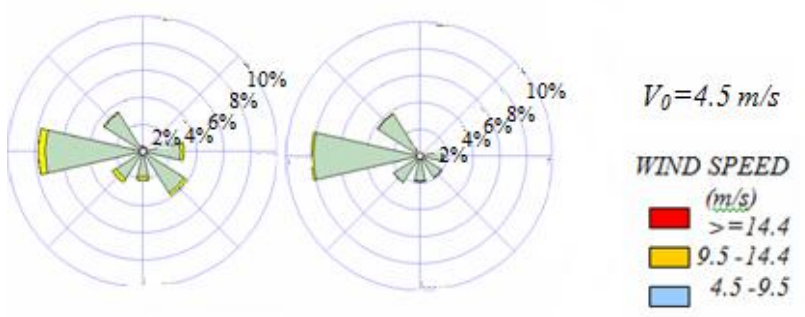

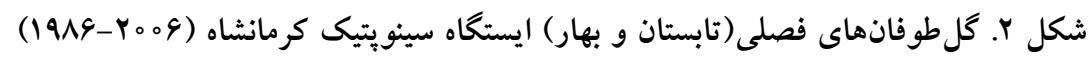

بهار
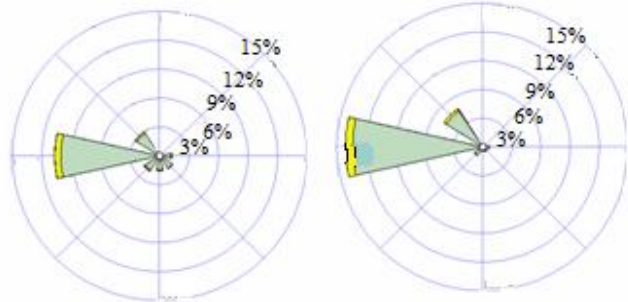

$V_{0}=4.5 \mathrm{~m} / \mathrm{s}$

WIND SPEED

$\square\left(\begin{array}{l}m / \mathrm{s}) \\ >=14.4\end{array}\right.$

$\square 9.5-14.4$

$\square$ 4.5-9.5

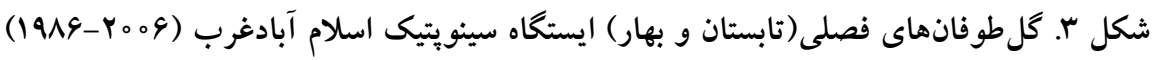

بيار

$$
\text { تابستان }
$$
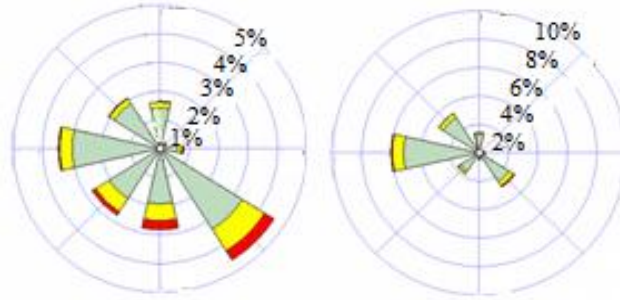

$V_{0}=4.5 \mathrm{~m} / \mathrm{s}$

WIND SPEED

$(\mathrm{m} / \mathrm{s})$

$>-14.4$

$\square 9.5-14.4$

$\square 4.5-9.5$

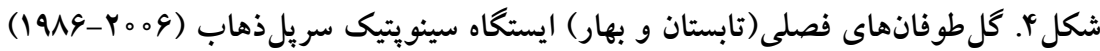

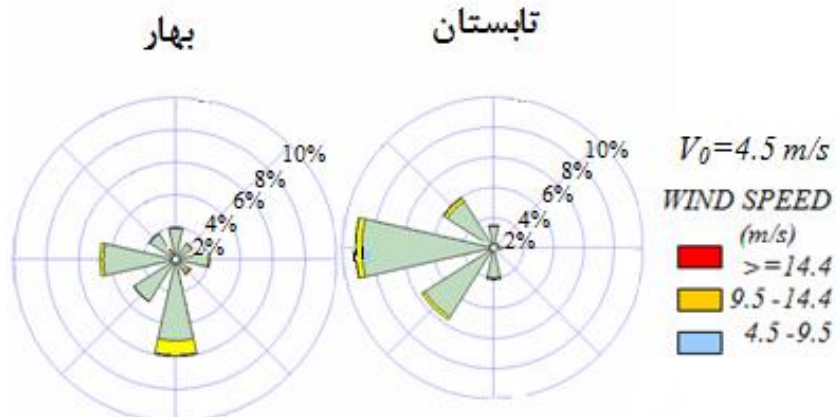

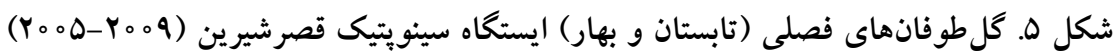




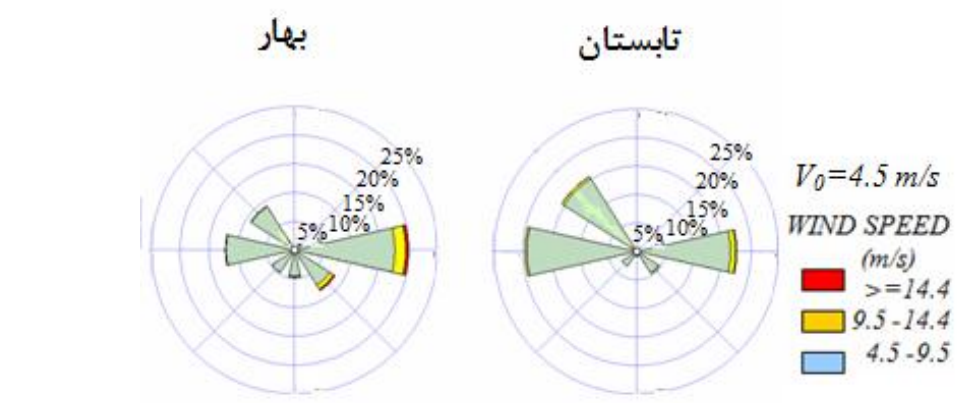

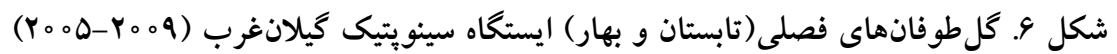

جدول r. آمارههاى توصيفى عناصر ردياب زئوشيميايى در نمونههاى منابع ذرات معلق (خاك) (ppb) و شاخص عامل تورم واريانس(VIF) و آزمون كولموگروف - اسميرنوف يكنمونهاى

\begin{tabular}{|c|c|c|c|c|c|c|c|c|}
\hline Sig & $\mathrm{k}-\mathrm{s}$ & VIF & حداقل & حداكثر & ضريب تغييرات (\%) & انحر اف معيار & ميانخين & عناصر ردياب \\
\hline $0 / \mu Y$ & $0 / 9$ & $10 / T$ & rN/ץ & $49 / 0$ & $r / \Lambda$ & $1 / 9$ & $Y \backslash / \wedge D$ & $\mathrm{Cr}$ \\
\hline$\circ / \circ \circ$ & $r / \mu$ & $r / \omega$ & $9 \circ 0 / 9$ & $\mid r \wedge \& / 0$ & $r q / \mu$ & TYY/V & $199 / \pi 9$ & $\mathrm{Zn}$ \\
\hline $0 / 01$ & $1 / 0$ & $N / \circ V$ & $1099 / 0$ & $r \circ \circ q / 1$ & $1 T / 9$ & T19/1 & 1999/Tr & $\mathrm{Cu}$ \\
\hline$\circ / 0 \circ$ & $1 / \mathrm{V}$ & $r / \Lambda$ & V9G/V & $1091 / 4$ & $r \circ / 4$ & rTq/K & $\| r \mid / A$ & $\mathrm{~Pb}$ \\
\hline $0 / 01$ & $1 / 9$ & $T / \Gamma$ & $r M / \circ r$ & $\varphi Q / \varphi$ & IV/V & $\Delta / \mu$ & $r q / 9 V$ & $\mathrm{Cd}$ \\
\hline$\circ / T \Delta$ & $\circ / 9$ & $T / V$ & $19 V 100$ & rovtoo & $14 / 01$ & raqor & $r 91910$ & K \\
\hline$\circ / \circ \mathrm{V}$ & $1 / r$ & $r / \circ r$ & IOVY०O० & 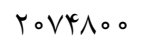 & $0 / 9$ & 111499 & 1419114 & $\mathrm{Ca}$ \\
\hline$\circ / 4 q$ & $\circ / 9$ & $r / 4 r$ & 9000 & IVY०。 & $1 \pi / 9$ & $\mid \wedge r q / 4 \wedge$ & $1 \pi 119 / 40$ & $\mathrm{Fe}$ \\
\hline$\circ / \circ \circ$ & $1 / \mathrm{V}$ & $\Delta / T V$ & $190 / / 9$ & $49 V V / r$ & $r 9 / 0$ & V৭\&/४A & 1991 & $\mathrm{Ni}$ \\
\hline$\circ / 0 \circ$ & $\circ / \wedge$ & T/DG & $1 r 0 / 19$ & $1 \Lambda \circ / V$ & $10 / \mu$ & $10 / 40$ & 100 & B \\
\hline$\circ / \circ \circ$ & $Y / 0$ & T/T & $\mu \circ \mu q / \circ \Lambda$ & $\Lambda G \wedge Y / \circ V$ & $r \Lambda / \mu$ & $|Y| Y / \Delta \Lambda$ & $49 \wedge 4 / V$ & $\mathrm{Se}$ \\
\hline$\circ / 00$ & $1 / \wedge$ & $r / 9 r$ & $r q \mu Y / r$ & $19 V D V / T V$ & $r N / \circ T$ & TVOV/AV & $q \wedge r q / 4$ & As \\
\hline ת & $0 / 9$ & $T / Y \Lambda$ & $\mathrm{r} / \Lambda$ & $0 / \Lambda$ & $\mathrm{V} / \mathrm{\Lambda}$ & $0 / 491$ & $0 / 09 \Lambda$ & Mo \\
\hline$\circ / V r$ & $0 / 9$ & $1 / 99$ & $0 \circ 9 / T$ & $11 \mu_{0} / 4$ & $1 \pi / 9$ & $109 / 9$ & $\vee \wedge \bowtie / \wedge$ & V \\
\hline ०/AY & $0 / 9$ & $1 / 40$ & ITYY/T & $r \circ 90 / 9$ & $9 / 9$ & $199 / \mathrm{TV}$ & $19 \mathrm{~V}$ & Co \\
\hline $0 / \mu 1$ & $0 / 9$ & $0 / 9 T$ & loY०o & TVYOO & $11 / \mu$ & rGAKM & rTq0Q/TD & $\mathrm{P}$ \\
\hline$\circ / 0 \circ$ & $T / l$ & F/AT & IVYYOO & $r q 1100$ & $r \mid / \Lambda$ & QVDTV/०Q & TATYNA & $\mathrm{Mg}$ \\
\hline.$/ 09$ & $\circ / 0$ & $1 / 4 r$ & ryq100 & $\vee 190 \circ \circ$ & $1 Y / 0$ & GOVDG/GY & DYFYIV & $\mathrm{Na}$ \\
\hline
\end{tabular}

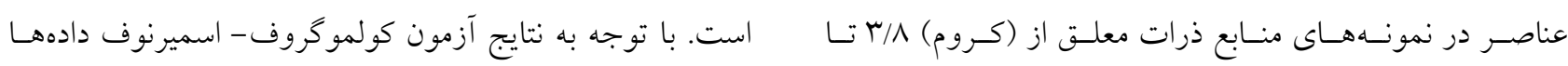

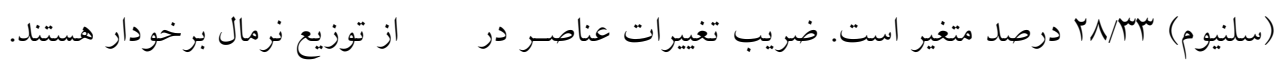

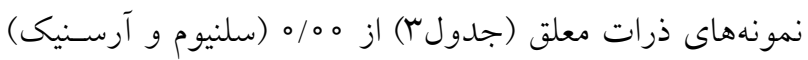

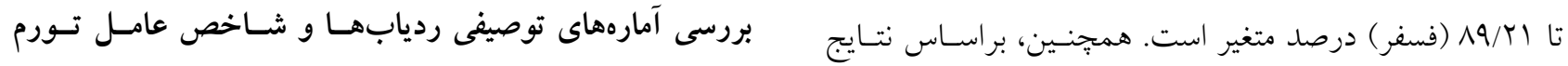

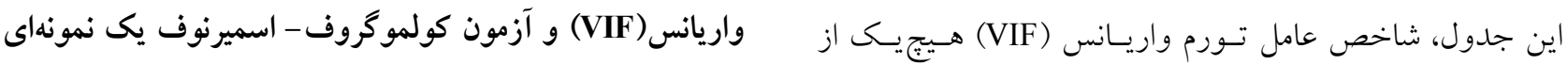

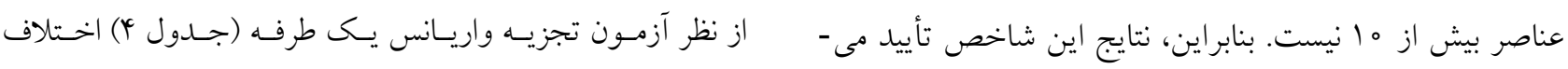

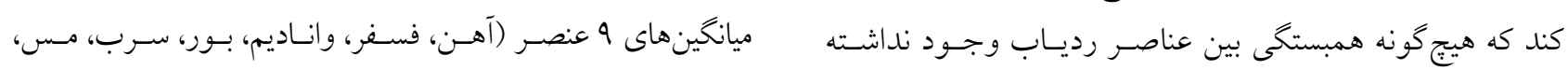


جدول r. آمارههاى توصيفى عناصر ردياب زئوشيميايى در نمونههاى ذرات معلق (ppb)

\begin{tabular}{|c|c|c|c|c|c|}
\hline حداقل & حداكثر & ضريب تغييرات (\%) & انحر اف معيار & ميانگين & عناصر ردياب \\
\hline$\mu \mathrm{m} / 0 \mathrm{G}$ & $0 \circ / 00$ & $Q / Y Y$ & $T / 9$ & $4 q / 0 \wedge$ & $\mathrm{Cr}$ \\
\hline YT००/०。 & $\mid Y K \circ 0 / 00$ & $r q / 99$ & Y० $49 / 9 \wedge$ & $991 \% / 0 Y$ & $\mathrm{Zn}$ \\
\hline $40 / 19$ & $r \circ Q / 9 T$ & MG/Dr & $r \Delta / \mu r$ & $99 / 99$ & $\mathrm{Cu}$ \\
\hline$\Lambda / 90$ & $\mid \Lambda N / 1 \circ$ & $99 / \mathrm{VI}$ & $G Y / 09$ & $\wedge 9 / \vee \wedge$ & $\mathrm{Pb}$ \\
\hline $11 / 4$ & ro/l。 & G/VY & سחו & $19 / 19$ & $\mathrm{Cd}$ \\
\hline Y100/00 & $10 \mu_{0} 0 / 00$ & $r q / A V$ & $|\wedge 4| / 19$ & $9190 / 00$ & $\mathrm{~K}$ \\
\hline $14 x \circ 0 / 00$ & $14900 \%$ & ( & $19 M M Y / 01$ & OYTI\% \% & $\mathrm{Ca}$ \\
\hline$\vee 00 / 00$ & ץへ००/०。 & $49 / 94$ & VOT/QD & $1914 / 90$ & $\mathrm{Fe}$ \\
\hline$m 1 / r q$ & rG०/०0 & $\Lambda T / Y r$ & YN/9G & $\Delta Q / 0 Y^{\circ}$ & $\mathrm{Ni}$ \\
\hline TSO०/०० & $100 \circ \circ / 0 \circ$ & MT/MY & $\mu \circ \mu \circ / v 1$ & $q r v \circ / 00$ & B \\
\hline $0 \%$ & $\Delta \circ / \circ \circ$ & $\circ / 0 \circ$ & $\%$ & $0 \% / \circ$ & $\mathrm{Se}$ \\
\hline $0 \%$ & $\Delta \circ / \circ \circ$ & $\circ / 0 \circ$ & $\circ / 00$ & $0 \%$ & As \\
\hline IV/TV & $r \circ / 0$ & $r / \circ D$ & $0 / 41$ & $19 / 94$ & Mo \\
\hline$\Delta \circ / \circ \circ$ & $9 \circ / 00$ & $\mid N / 4 \Lambda$ & $10 / 1 r$ & $\Delta F / V Q$ & V \\
\hline Y/A & $r \Delta / v q$ & KY/TH & $q / T \Delta$ & $Y Y / 90$ & Co \\
\hline $0.0 \%$ & YY०O/०० & $\Lambda 9 / Y 1$ & $099 / 99$ & $9 V Y / 0 \circ$ & $P$ \\
\hline ץ。०/०。 & $V 900 / 0 \circ$ & $\mathrm{VQ} / \Delta \mathrm{V}$ & $1940 / 4 V$ & Y०9V/A० & $\mathrm{Mg}$ \\
\hline $9000 / 00$ & $r \Delta Q \circ \%$ & YG/YY & Prgr/A。 & $190 \circ Y / 0 \circ$ & $\mathrm{Na}$ \\
\hline Y०/०० & $10 \% \%$ & $91 / 19$ & TN/9D & $4 \& / \Lambda 9$ & $\mathrm{Mn}$ \\
\hline$G N / 4 V$ & $r r q 00 / 00$ & $r q / \circ \Lambda$ & OrVQ/AV & 1 Irqas/va & $\mathrm{Al}$ \\
\hline
\end{tabular}

آمـاره ويلكـس لامــدا، معيـارى از نسـبت اخـتلافهــــ درون كروهى به اخـتلافهـاى بـين گروهـى اسـت. در هـر مرحلـه، متغيرى وارد تابع شده كه در سطح ينج درصد يا كمتر معنسى بوده و بيشترين فاصله ماهالانوبيس را داشته باشد. عنصر فسـفر،

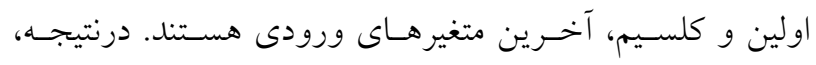
تركيب بهينهاى كه قادر به جداسـازى واحسدهاى زمسينشناسى لهى باشد، متشكل از جهار عنصـر (فسـفر، وانـاديم، بـور و كلسـيم) اسـت. بقيـه عناصسر بـا داشـتن آمـاره F بيشـتر از يـنج درصــ (براى ورود) و بهعلت نداشـتن تـوان جداسـازى كـافى حـذف لـ

شدهاند.

\section{واحدهاى زئومورفولوزى}

جدول (9) مراحل مختلف اضافه شدن عناصر ردياب در توابـع

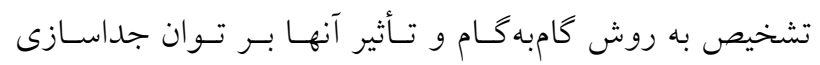
تحليـل تشـخيص بــراى واحســهاى زئومورفولــوزى را نشــان
يتاسيم، كلسيم و موليبدن) در سطح ه ا درصد معنسى دار اسـت كـه بيانكر اين مطلب است كه عناصر ياد شده، داراى قدرت تفكيـى و جداسازى واحدهاى زمينشناسى مىباشند. همجنين، براسـاس ايسن

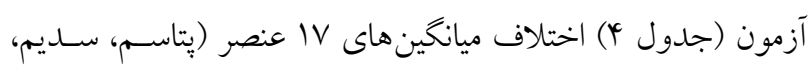

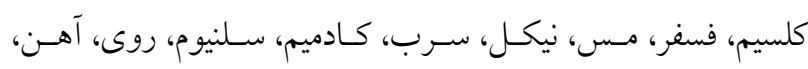
منيزيم، بور، كبالت، آرسنيك، موليبدن و وانـاديم) در سـطح معنى دارى يك درصد و يك عنصر (كروم) در سطح ه ا درصد معنى دار است كه بيانكر اين مطلب است كه عناصر ياد شـده، داراى قـدرت تفكيك و جداسازى واحدهاى زئومورفولوزى هستند.

تحليل تشخيص و انتخاب تركيب بهينه واحدهاى زمين شناسى جدول (ه) مراحل مختلف اضافه شدن عناصر ردياب در توابـع

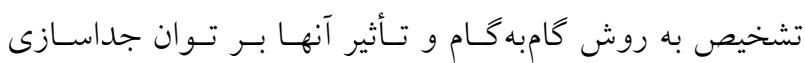
تحليل تشخيص براى واحدهاى زمينشناسى را نشان مسىدهـد. 
جدول ₹ا. نتايج آزمون تجزيه واريانس يكطرفه براى بررسى توان عناصر در جداسازى واحدهاى زمينشناسى

و واحدهاى زئومورفولوزى برى تراي

\begin{tabular}{|c|c|c|c|c|}
\hline \multicolumn{2}{|c|}{ واحدهاى زئومورفولوزى } & \multicolumn{2}{|c|}{ واحدهاى زمينشناسى } & \multirow{2}{*}{ عناصر ردياب } \\
\hline سطح معنى دارى & 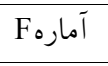 & سطح معنى دارى & 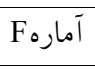 & \\
\hline ०/०VA & $1 / K T$ & o/AVI & $0 / 4+q$ & $\mathrm{Cr}$ \\
\hline$\circ / 000^{*}$ & $V / r Y$ & $0 / r_{01}$ & $1 / 49$ & $\mathrm{Zn}$ \\
\hline$\circ / 000^{*}$ & $\mid r / T V$ & $\circ / \circ \circ Y^{*}$ & $p / \circ q$ & $\mathrm{Cu}$ \\
\hline$\circ / 0 \circ 0^{*}$ & $11 / 1 r$ & $\circ / \circ 90^{*}$ & $1 / 9 r$ & $\mathrm{~Pb}$ \\
\hline$\circ / 000^{*}$ & $Q / \circ V$ & $\circ / \mathrm{VIV}$ & $0 / 94$ & $\mathrm{Cd}$ \\
\hline$\circ / 0 \circ 0^{*}$ & $Y / \Lambda Y^{4}$ &.$/ 019^{*}$ & r/9T & $\mathrm{K}$ \\
\hline ००००* & $9 \pi \mathrm{V}$ & $\circ / Y^{*} \mathcal{G}^{*}$ & r/GY & $\mathrm{Ca}$ \\
\hline$\circ / \circ \circ \circ^{*}$ & $9 / \pi q$ & $\circ / \circ \varphi^{*}$ & $T / P Q$ & $\mathrm{Fe}$ \\
\hline$\circ / 0 \circ 0^{*}$ & $11 / 91$ & ०/ITD & 1/V9 & $\mathrm{Ni}$ \\
\hline$\circ / 0 \circ 0^{*}$ & $\Delta / \circ \wedge$ & $\circ / 001^{*}$ & $Y / Q V$ & B \\
\hline$\circ / 0 \circ 0^{*}$ & T/AV & $\circ / N T^{\prime}$ & $0 / 9 Y$ & $\mathrm{Se}$ \\
\hline$\circ / \circ \circ \circ^{*}$ & $r / 90$ & $\circ / Y \circ Y^{r}$ & $1 / 4 \wedge$ & As \\
\hline$\circ / 0 \circ 0^{*}$ & $r / 91$ &.$/ \circ 9 Y^{*}$ & T/19 & Mo \\
\hline$\circ / 0 \circ 0^{*}$ & $r / 91$ &.$/ 014^{*}$ & $r / 99$ & $\mathrm{~V}$ \\
\hline ०/०००** & $r / 90$ & - DYG & $\circ / \Lambda \Lambda$ & Co \\
\hline ०/०००* & $10 / V G$ & $\circ / \circ \circ r^{*}$ & $\varphi / \| r$ & $\mathrm{P}$ \\
\hline ०/०००** & $9 / 90$ & ०/TQG & $1 / 1 \omega$ & $\mathrm{Mg}$ \\
\hline ०/०००** & $\Gamma / \Lambda$ & o/IVD & $1 / 0 V$ & $\mathrm{Na}$ \\
\hline
\end{tabular}

\begin{tabular}{|c|c|c|c|c|}
\hline سطح معنى دارى F & ويلكس لامدا & حداقل مربع فاصله ماهالانوبيس & اضافه شدن عنصر ردياب & كام \\
\hline O००Y & $\circ / \Delta \Delta^{\circ}$ & $0 / 011$ & $\mathrm{P}$ & 1 \\
\hline$\circ / 0 \circ 0$ & $0 / \mu K Y$ & $0 / 04 \wedge$ & V & r \\
\hline$\circ / 0 \circ 0$ & $0 / M Y Y$ & $0 / 0 V 1$ & B & r \\
\hline$\circ / 0 \circ 0$ & $0 / 1 T$ & $\circ / \circ V Q$ & $\mathrm{Ca}$ & r \\
\hline
\end{tabular}

كروهها (واحدهاى زئومورفولـوزى) شـده اسـت. مقــادير مربـع فاصـله ماهــالانوبيس، ويلكــس لامـــا در خــام اول بــةترتيـبـ

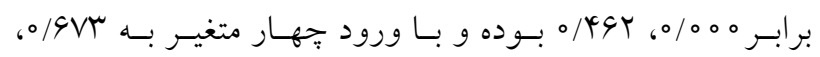
ه० ○/ رسيده است. درنتيجه، تركيب مناسبى از عناصر كه قـادر به جداسازى واحسـهاى زئومورفولـوزى اسـت، متشـكل از 11

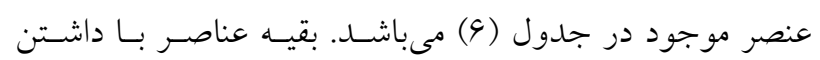

مى دهد. با توجه به جدول ياد شده ملاحظه مى شـود، بـا اضـافه شدن هر عنصر مقدار ويلكس لامدا كاهش و سـطح معنسى مارى بهتر شده اسـت و در نتيجـهـ تـوان جداسـازى تحليـل و ميـزان تفكيك بين كروهها افزايش يافته است. عنصـر ســيم، اولـين و عنصر كلسيم، آخرين متغيرهاى ورودى هستند. كاهش ويلكس لامدا و افـزايش فاصسله ماهـالانوبيس باعـث افـزايش اخـــلاف 
جدول و. گامهاى مختلف ورود عناصر به مدل و تأثير آنها بر توان جداسازى تحليل تشخيص واحدهاى زئومورفولوزى

\begin{tabular}{|c|c|c|c|c|}
\hline سطح معنى مارى & ويلكس لامدا & حداقل مربع فاصله ماهالانوبيس & اضافه شدن عنصر ردياب & 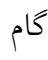 \\
\hline$\circ / 0 \circ 0$ & $0 / 4 G Y$ & ०/००० & $\mathrm{Na}$ & 1 \\
\hline ०/००० & $0 / 091$ & $0 / 01 Y$ & $\mathrm{Cu}$ & r \\
\hline ०/००० & $0 / 009$ & 01099 & $\mathrm{Co}$ & $r$ \\
\hline$\circ / 0 \circ 0$ & ०/०० & -/lQH & $\mathrm{Cd}$ & r \\
\hline$\circ / 000$ & $0 / 001$ & $\circ / Y_{0} \circ$ & As & 0 \\
\hline \%/००० & $0 / 001$ & - DTA & Mo & 9 \\
\hline \%००० & $\circ / 0 \circ 0$ & $0 / 199$ & $\mathrm{~Pb}$ & V \\
\hline ०/००० & ०/००० & $0 / 941$ & $\mathrm{~K}$ & $\wedge$ \\
\hline \%००० & $\circ / 000$ & $0 / 9 G \mu$ & $\mathrm{Ni}$ & 9 \\
\hline \%००० & $\circ / 0 \circ 0$ & $0 / 9 \mathrm{VI}$ & $\mathrm{Mg}$ & 10 \\
\hline \%०००० & \% 000 & $0 / 9 V \mu$ & $\mathrm{Ca}$ & 11 \\
\hline
\end{tabular}

جدول V. سهم واحدهاى زمينشناسى در توليد ذرات معلق

\begin{tabular}{|c|c|c|c|}
\hline موقعيت و احد & سهم كل (درصد) & درصد مساحت تحت بوشش & واحد زمين شناسى \\
\hline قصرشيرين و تا حدودى گيلانغرب & 100 & $1 Y / 99$ & UF (مارن قرمز و ماسهسنگ) UF \\
\hline
\end{tabular}

جدول ^ـ سهم واحدهاى زئومورفولوزى در توليد ذرات معلق

\begin{tabular}{|c|c|c|c|}
\hline موقعيت واحد & سهم كل (درصد) & درصد مساحت تحت يوشش & واحد زئومورفولوزى \\
\hline قصرشيرين & 100 & $0 / \mu G$ & r \\
\hline
\end{tabular}

نشاندهنده دقت يايين مدل است.

\section{واحدهاى زئومورفولوزى}

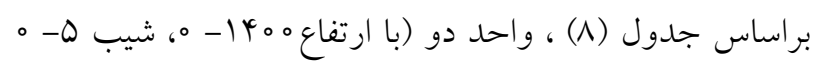

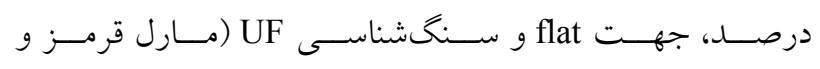

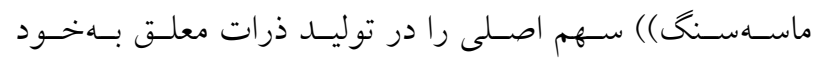
اختصاص داده است. اين واحد در منطقه قصرشيرين واقع شــه است. مجموع خطاى نسبى براى مـدل 9/ND.0ه بـهدست آمــده است. اين مقدار خطا نشاندهنده دقت بِايين مدل است.

\section{بحث}

براسـاس نتـايج حاصـل از ايـن مطالعـه، تركيـبـ بهينـهـ بــراى
آماره F در سطح معنى دارى بيشتر از يــنج درصسـ بـــاى ورود و بهعلت نداشتن توان جداسازى كافى حذف شدهاند. تعيين سهم هريك از منابع در توليد ذرات معلق واحدهاى زمين شناسى همانطوركه در ستون سوم جدول (V) ملاحظـه مسىشـود، تنهـا سازند UF كه ويزَّى سنخشناسى آن، مارن قرمز و ماسه سـنگ اسـت، در توليــد ذرات معلـتق ســهم دارد كــه در شهرسـتـان قصرشيرين واقع شده است. بقيه واحدها يا سـازندها، بـا توجـهـ به اينكه سهم آنها برابر صفر شده است، بنابراين اين واحدها يـا

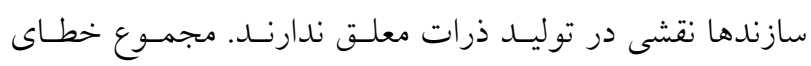
نسبى براى مدل سا/ ال بهدست آمـده اسـت. ايسن مقـدار خطـا 
كردند كه تشـابه در الخـوى توزيـع ذرات كردوغبـار و الخــىى

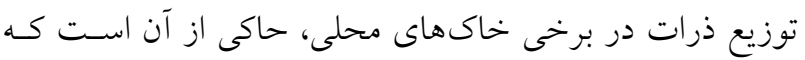
بخشى از ذرات ترسيب يافته داراى منشا محلى اسـت. در مقابـل

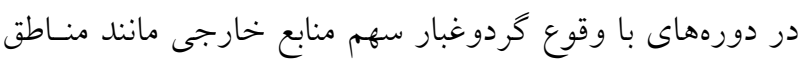
بيابانى در كشور عراق در توليد ذرات گردوغبار افزايش مى يابد.

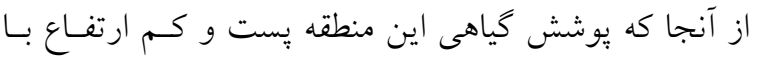

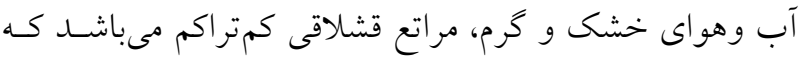

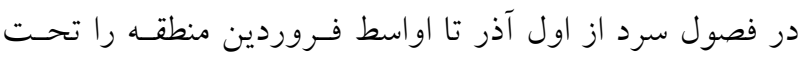
يوشش خود قرار دادهاند و در ساير فصول اين منطقه خشـى و نـ بدون يوشش است، بنابر اين بهدليل نداشتن يوشـش سطحى در

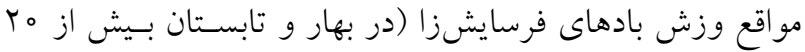
درصد بادها فرساينده هستند.) و عدم وجود بادشكن، اين منطقه مىتواند در توليد اين ذرات با منشا محلـى سـهم داشـته باشـد.

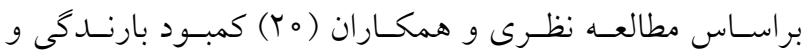
PM1。 رطوبت هوا، الكوهاى فصلى باد مىتوانند شرايط آلودگى بهويزه در فصول كرم سال را در كرمانشاه ايجاد كرده باشند. درنهايت مى توان بيان كرد كـه روش منشـايابى در تعيسين و

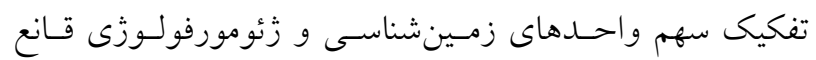

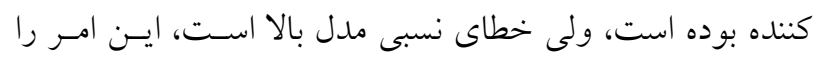

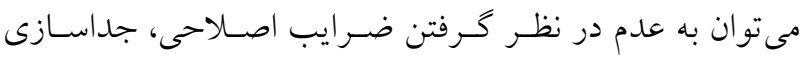
ذرات كوجكتر از بهو ميكرون و تعداد كم رديابهاى استـخراج شده نسبت به واحدها در آناليز تشخيص نسبت داد.

\section{نتيجه گيرى}

براساس روش منشايابى، سازند UF ( مارن قرمز و ماسه سنگ)

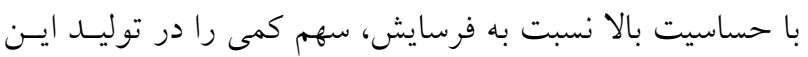
ذرات داشته است. همجنين، با توجه به اينكه منـاطق مـارنى در

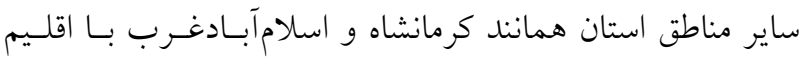

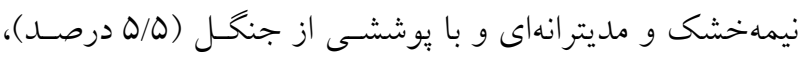

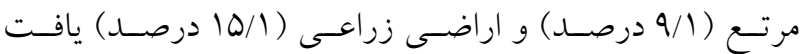

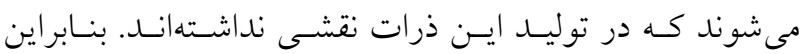
بيشنهاد مىشود با ايجاد بوشش كياهى مناسب و ديخر اقـدامات
جداسازى واحدهاى زمينشناسى، شـامل جهار عنصسر (بـور،

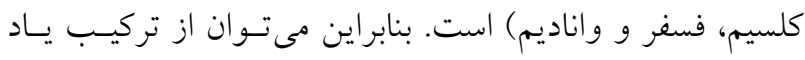

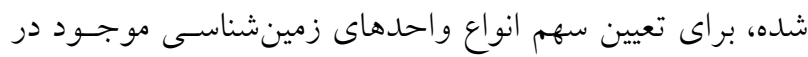
منطقـه مـورد مطالعـه اسـتفاده نمـود. در مطالعـه تيموريـان و

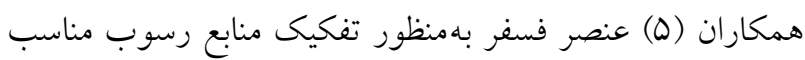

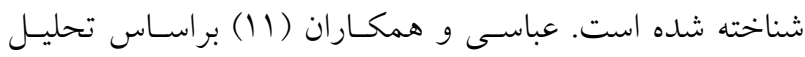
تشخيص عناصرى همانند فسفر و كلسـيم را بـهنعـوان تركيـب بهينـه انتخـاب كردنـــ. همجنـين، مناسـبتــرين تركيـب بــراى واحدهاى زئومورفولوزى متشكل از 11 عنصر (سرب، آرسنيك، مابك

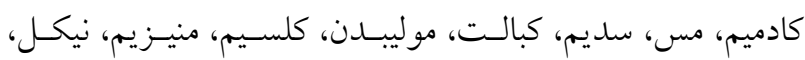

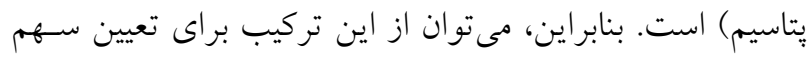

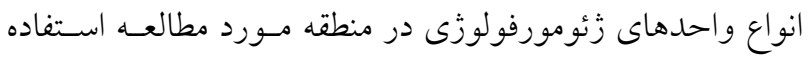
كرد. در مطالعه نجفى و صادقى (1N) عناصرى همانند آرسنيك،

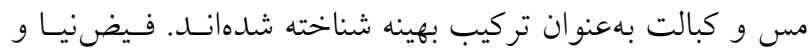
همكاران (l) با بهره كيرى از روش تحليل تشخيص دو ردياب

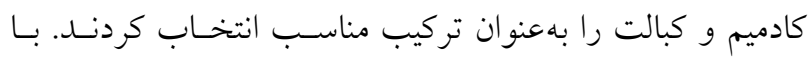
توجه به جدول (9)، از نظر سهم واحدهاى زمينشناسى، سازند

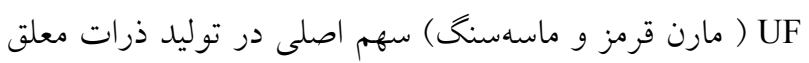

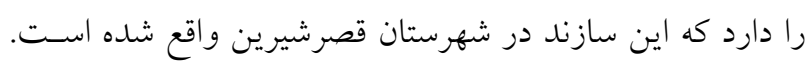

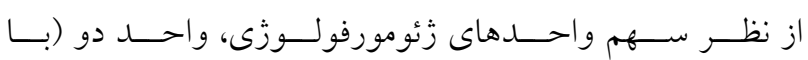

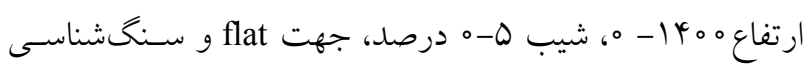

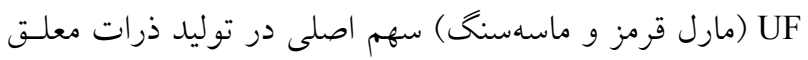

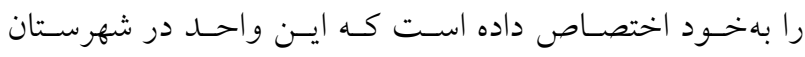

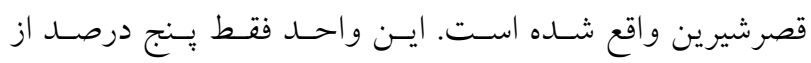
مساحت منطقه مورد مطالعه را بـهـــود اختصـاص داده اسـت.

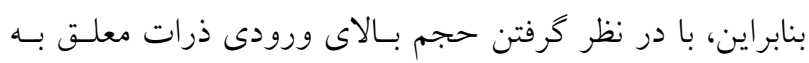

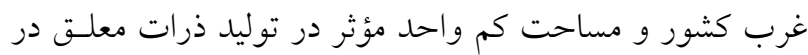

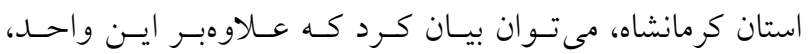
كشـورهاى همسـايه در توليـــ ايـن ذرات نقـش مهمسى را ايفـا مى كنند. با توجه به نقشه تكتونيك خاورميانه، اين واحد از نظـر ويزّكى زمينشناسى با زمينشناسى كشـورهايى هماننــ عـراق،

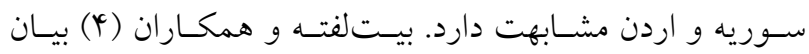


كنترلى مناسب در اين مناطق، بهمنظور جلـو گيرى از فرسـايش

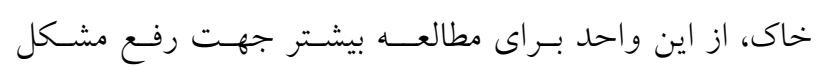

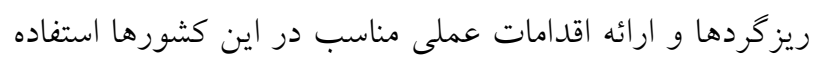

شود.
عملى از فرسايش خاك در مناطق مستعد به فرسـايش و صـود

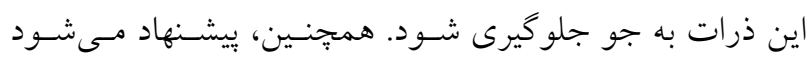

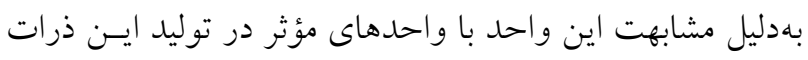

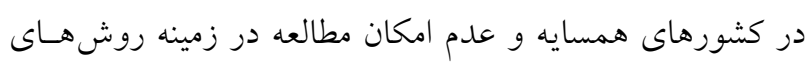

\section{منابع مورد استفاده}

ا. اختصاصى، م.rیזا. بررسى مورفومترى و مورفوديناميك رخسارههاى فرسايش بادى دشت يزد- اردكان و تعيين شاخصهاى اين

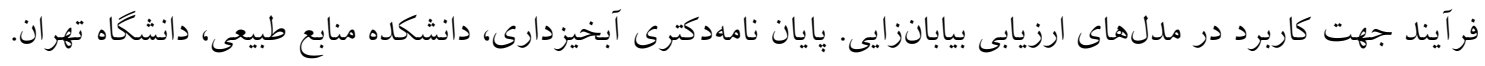

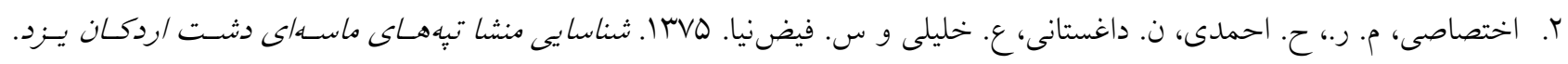

$$
\text { مؤسسه تحقيقاتى سازمان جنغال ها و مراتع. ايران. }
$$

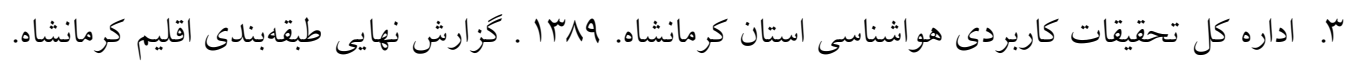

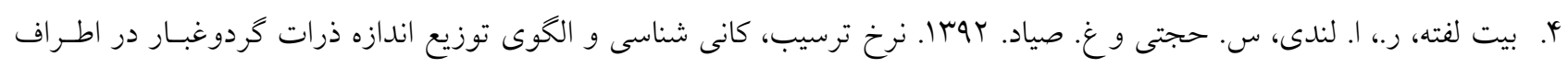

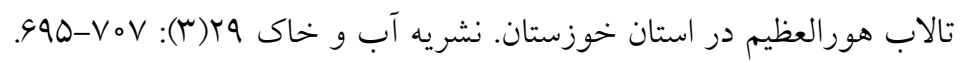

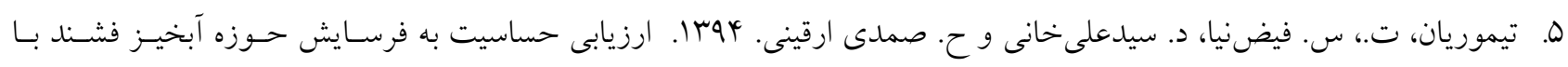

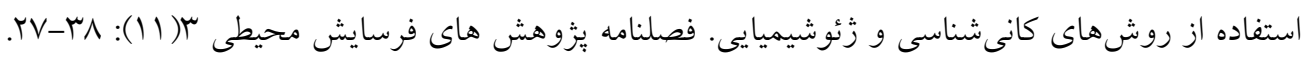

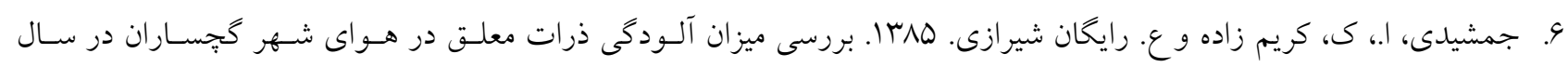

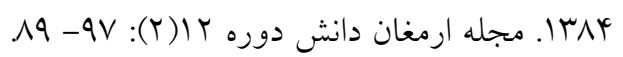

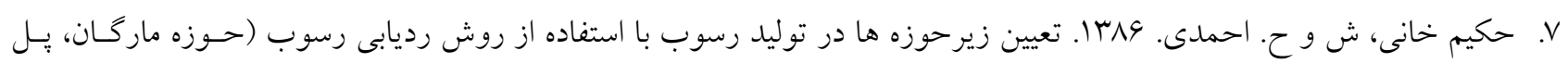

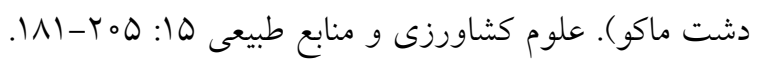

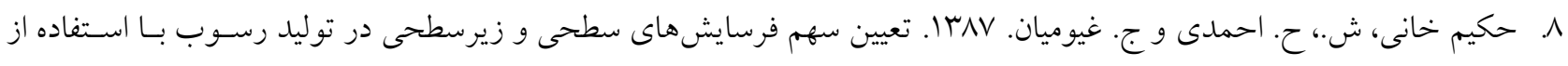

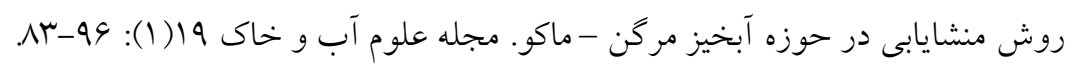

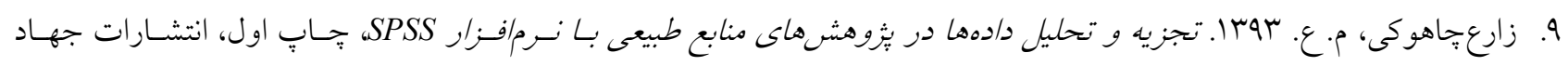
دانشخاهى واحد تهران، تهران.

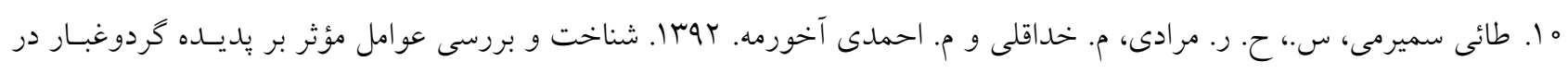

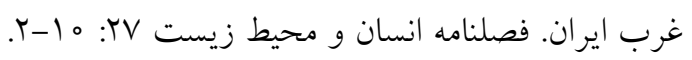

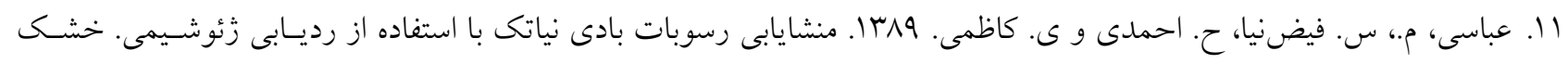

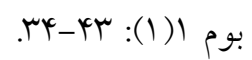

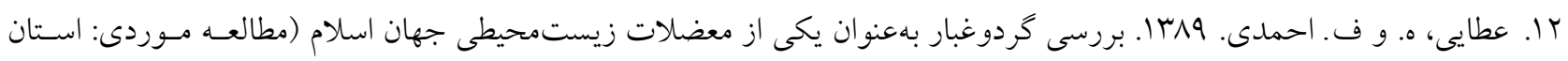

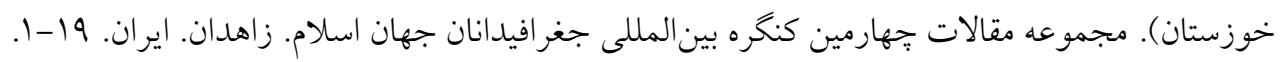

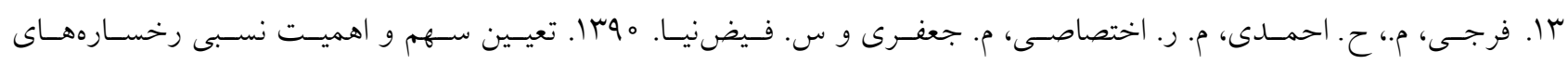

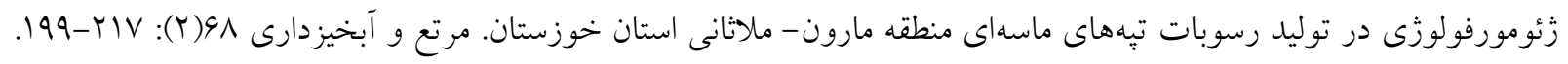

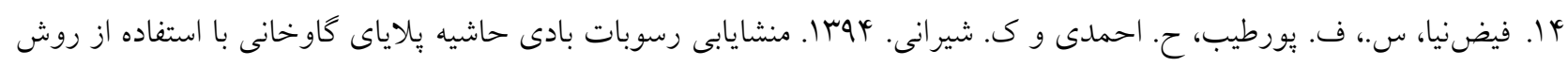




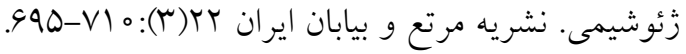

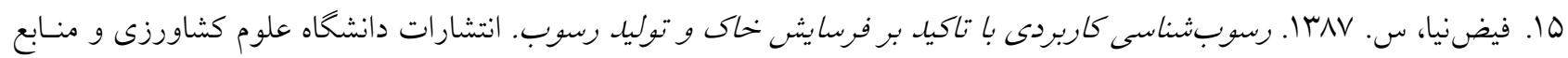

$$
\begin{aligned}
& \text { طبيعى گر كان. }
\end{aligned}
$$

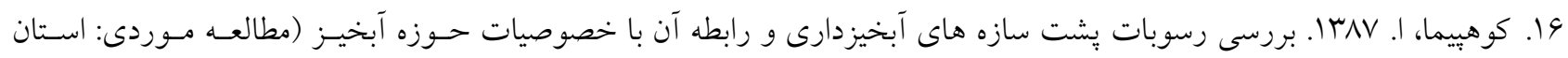

$$
\begin{aligned}
& \text { سمنان). ياياننامه كارشناسى ارشد رشته مهندسى آبخيزدارى. دانشكده منابع طبيعى و كشاورزى. دانشخاه تهران. }
\end{aligned}
$$

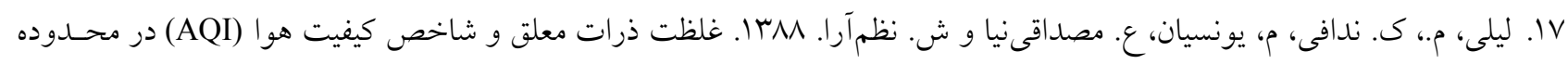

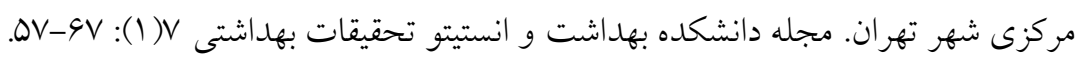

$$
\begin{aligned}
& \text { 1/. نجفى، س. و ح. ر. صادقى. rوبا. تعيين سهم منابع رسوب از طريق مقايسه نتايج روش هاى تهيه نقشه سيماى فرسايش. انخشت }
\end{aligned}
$$

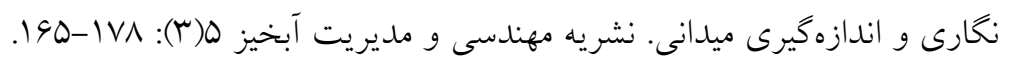

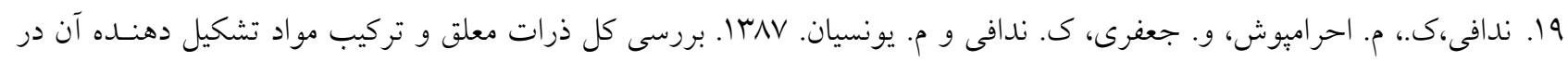

$$
\begin{aligned}
& \text { منطقه مركزى شهر يزد. مجله دانشخاه علوم بزشكى و خدمات بهاشتى درمانى شهيد صدوقى يزد ؟|(Y): }
\end{aligned}
$$

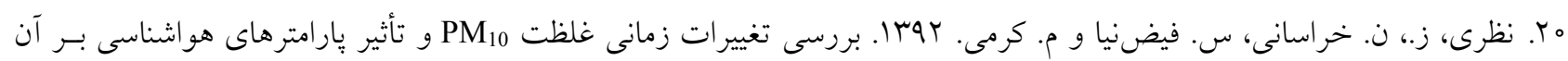

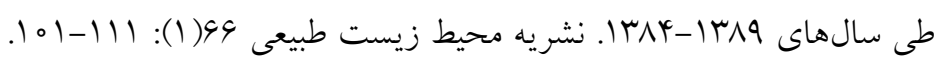

21. Cao, J., Zh. Shen, C. J. Chow, G. Qi and G. J. Watson. 2009. Seasonal variations and sources of mass and chemical composition for PM10 aerosol in Hangzhou, China. Particuology 7: 161-168.

22. Chappel, A. and A. Warren. 2003. Spatial scales of 137 Cs- derived soil flux by winina $25 \mathrm{~km}^{2}$ arable area of eastern England. Elsevier 52: 209-234.

23. Collins, A. L., D. E. Walling and G. J. L. Leeks. 1997. Source type ascription for fluvial suspended sediment based on a quantitative composite fingerprinting technique. Catena 29: 1-27.

24. Collins, A. L., D. E. Walling. 2004. Documenting catchment suspended sediment sources: problems, approaches and prospects. Phys. Geogr. 28: 159-196.

25. Loughran, R. J., B. L. Campbell. 1995. The identification of catchment sediment sources. PP: 189-205. In: I. D. L. Foster, A. M. Gumell and B. W. Webb (Eds.), Sediment and Water Quality in River Catchments. Wiley, Chichester.

26. Ping, Y., D. Zhibao, D. Guangrong, Y. Xinbaos and Z. Yun. 2001. Prelim inary results of using 137 Cs testily wind erosion in the Qing hai-Tibext plateau. Arid Environ. 47: 443-452.

27. Walling, D. E. 2005. Tracing suspended sediment sources in catchments and river systems. Sci. of the Total Environ. 344: 159-184.

28. Walling, D. E., P. N. Owens and G. J. L. Leeks. 1999. Fingerprinting suspended sediment sources in the catchment of the River Ouse, Yorkshire, UK. Hydrol. Process. 13: 955-975. 


\title{
Source Identification of Aerosols in Atmosphere Using Geochemical Properties of Tracer Elements (The Case Study Area: City of Kermanshah)
}

\author{
Z. Nazari ${ }^{1 *}$, N. Khorasani ${ }^{1}$, S. Feiznia ${ }^{2}$ and M. Karami ${ }^{1}$
}

(Received: March 6-2017; Accepted: May 15-2017)

\begin{abstract}
The purpose of this research was source identification of aerosols in atmosphere using geochemical properties in the city of Kermanshah. The concentrations of twenty elements consisting of $\mathrm{K}, \mathrm{Na}, \mathrm{Ca}, \mathrm{P}, \mathrm{Cu}, \mathrm{Ni}, \mathrm{Pb}, \mathrm{Cd}, \mathrm{Se}, \mathrm{Zn}, \mathrm{Fe}, \mathrm{Mg}$, B, Cr, Co, As, Mo, V were analyzed by ICP for 55 soil samples (in the height range of $600-1600 \mathrm{~m}$ ) and 41 aerosols samples. Source identification of aerosels using geochemical tracers was performed in two steps. In the first step, appropriate combination of tracer elements with high ability in the resolation of aerosol sources was chosen using the means comparison test and discriminate analysis. In the second step, the multivariate mixing model was used to determine the contribution of aerosol sources (geological and geomorphology types) to the production of aerosols in the study area. The results obtained from determination of the contributions of sources of aerosols (geological and geomorphological types) showed the UF formation (consisting of red marl and sandstone), with the height of 0-1400 mand the slope of $0-5 \%$, could be regarded as the main contributor to the production of aerosols located in the city of Qasreshirin.
\end{abstract}

Keywords: Climate; $\mathrm{PM}_{10}$; Contribution; Multivariate mixing model; Natural sources.

1. Dept. of Environ. Sci., College of Agric. and Natural Resour., Univ. of Tehran, Tehran, Iran.

2. Dept. of Reclamat. of Arid and Mountain. Regions, College of Agric. and Natural Resour., Univ. of Tehran, Tehran, Iran.

*: Corresponding Author, nazarizeinab4@gmail.com 